\title{
APPLICATION OF NOVEL NATURAL POLYMER FOR CONTROLLING THE RELEASE OF FENOVERINE FROM CONTROLLED RELEASE MATRIX TABLETS
}

\section{AJIT KULKARNI*, TRUSHALI MANDHARE, NAGESH ALOORKAR}

\author{
Satara College of Pharmacy, Satara, New Additional MIDC, A/P-Degaon, Satara [MS], India 415004
}

Email: ajitkulkarni123@gmail.com

Received: 24 Nov 2016, Revised and Accepted: 02 Mar 2017

Abstract

Objective: To explore a novel natural polymer, pullulan for controlling the release of fenoverine from matrix tablets and to elucidate the release kinetics of fenoverine from pullulan and HPMC matrices.

Methods: In this study we formulated monolithic matrix tablets containing of fenoverine as controlled-release tablets by direct compression using pullulan, HPMC (Hydroxypropyl methyl cellulose) K4M and HPMC K100M polymers and evaluated for hardness, thickness, friability, weight variation drug content, in vitro drug release characteristics and FTIR (Fourier transform infrared spectroscopy) and DSC (Differential scanning calorimetry) study.

Results: All the formulations showed compliance with pharmacopoeial standards. FTIR and DSC study indicated the absence of interaction between fenoverine and excipients. The formulation was optimized on the basis of acceptable tablet properties and in vitro drug release. The results of dissolution studies indicated that the formulation F5 [drug to polymer 1: 0.35 ] exhibited highest \% cumulative drug release of $96.82 \pm 0.75 \%$ at the end of $12 \mathrm{~h}$. Optimised batch F5 showed super case II transport mechanism and followed zero order release kinetics. Short-term stability studies of the optimized formulation indicated that there were no significant changes observed in hardness, drug content and in vitro dissolution studies at the end of three months period. Similarity factor $f 2$ was found to be 89 , which indicated similar dissolution profiles before and after stability study.

Conclusion: Based on above results we conclude that pullulan can be used as a polymer for retarding the release of drug from matrix formulations.

Keywords: Pullulan, Fenoverine, Hydroxypropyl methyl cellulose, Controlled release, In vitro

(C) 2016 The Authors. Published by Innovare Academic Sciences Pvt Ltd. This is an open access article under the CC BY license (http://creativecommons.org/licenses/by/4.0/) DOI: http://dx.doi.org/10.22159/ijap.2017v9i2.16318

\section{INTRODUCTION}

Controlled release systems include any drug delivery system that achieves slow release of drug over an extended period of time. Possible benefits of a properly designed controlled release dosage form include low cost, simple processing, improved efficacy, reduced adverse events, flexibility in terms of the range of release profile attainable, increased convenience and patient compliance $[1,2]$. In recent years oral, controlled drug delivery systems have gained increased importance and interest since it is necessary to improve the systemic absorption of the drugs and patient compliance. In addition, controlled drug delivery systems maintain uniform drug levels, reduce the dose, side effects, and increase the safety margin. There are several types of controlled release systems that are designed and categorized according to the mechanism they employ. These include diffusion controlled, dissolution controlled, erosion controlled, ion exchange controlled and transport controlled also known as osmotic pump system [3, 4, 30]. Matrix controlled release tablet formulations are the most fashionable and straightforward to formulate on a commercial scale. Matrix tablets serves as an important tool for oral controlled-release dosage forms. Hence, problems of conventional dosage forms, like patient noncompliance, local side effects, frequent administration and fluctuations in blood concentration levels were solved. Oral controlled release drug delivery system becomes a very promising approach for those drugs that are given orally but having the shorter half-life and high dosing frequency [1]. Matrix tablets may be formulated by wet granulation or direct compression methods by dispersing solid particles within a porous matrix formed of hydrophilic and hydrophobic polymers [5]. The drug release in matrix drug delivery systems occur by both dissolution-controlled as well as diffusion controlled mechanisms [6-8]. The present work was intended to explore the natural polymer obtained from Aureobasidium Pullulan [9, 10, 26-29]. This natural polymer is extremely hydrophilic in nature. This polymer has been used for film forming ability by other researchers, novelty of study is its use as release retarding agent has not been explored. Fenoverine is chemically 10[4-piperonyl [1-piperazinyl] acetyl] phenothiazine with molecular formula $\mathrm{C}_{26} \mathrm{H}_{25} \mathrm{~N}_{3} \mathrm{O}_{3} \mathrm{~S}[11,12]$. Fenoverine is an antispasmodic drug. It is used to relieve muscle spasm, used for disorders of the colon [Irritable bowel syndrome], abdominal pain, etc. $[13,14]$. Fenoverine acts by modulating the gradient of calcium ions through the cell membrane. Fenoverine due to its poor aqueous solubility and poor wettabilty, less protein binding and its short biological half-life [5 to $7 \mathrm{~h}$ ] and therapeutic use in chronic conditions necessitates its formulation into controlled release dosage form $[15,16]$. The objective of this investigation was to explore pullulan for its drug release controlling characteristics from controlled release dosage form.

\section{MATERIALS AND METHODS}

\section{Materials}

Fenoverine was a gift from Euro drug Laboratories, Hyderabad, India. HPMC K4M was procured from SD Laboratories, Mumbai, India, HPMC K100M from Research Lab., Fine Chemicals, Mumbai, India. Pullulan was procured from Gangaval chemicals, Mumbai, Spray dried lactose was obtained from Okasa Pharma, Satara, India. Talc and magnesium stearate were purchased from Loba Chemie Pvt. Ltd., Mumbai, India. All other ingredients used throughout the study were of analytical grade and were used as received.

\section{Methods}

\section{FTIR spectrum of fenoverine}

The IR spectrum of fenoverine was recorded using Fourier transform infrared spectroscopy [ATR-FTIR] to check its purity. The spectrum was recorded over the wave number of 4000 to $400 \mathrm{~cm}^{-1}[19,20]$.

\section{Differential scanning calorimetry [DSC] of Fenoverine}

DSC study was carried by using Mettler-Toledo DSC $821^{\mathrm{e}}$ instrument [Switzerland]. About $2 \mathrm{mg}$ of the fenoverine was sealed in the aluminum pan and heated at the rate of $10{ }^{\circ} \mathrm{C} / \mathrm{min}$, covering a 
temperature range of $30^{\circ} \mathrm{C}$ to $200{ }^{\circ} \mathrm{C}$ under a nitrogen atmosphere, at flow rate of $40 \mathrm{ml} / \mathrm{min}$ [21].

\section{Drug-polymer compatibility study}

\section{FTIR study}

FTIR spectra of HPMC K4M, HPMC K100M, pullulan and physical mixtures of fenoverine with polymer were recorded to study the interaction between them. The spectra were recorded over the wave number of 4000 to $400 \mathrm{~cm}^{-1}[19,20]$.

\section{DSC study}

In order to assess the compatibility of fenoverine with a polymer, thermogram of pure fenoverine, HPMC K4M, HPMC K100M, pullulan polymers and formulations were recorded using Mettler-Toledo DSC $821^{\mathrm{e}}$ instrument [Switzerland]. About $5 \mathrm{mg}$ of the physical mixture was sealed in the aluminium pan and heated at the rate of 10 ${ }^{\circ} \mathrm{C} /$ min, covering a temperature range of $30{ }^{\circ} \mathrm{C}$ to $200{ }^{\circ} \mathrm{C}$ under a nitrogen atmosphere, at a flow rate of $40 \mathrm{ml} / \mathrm{min}[21,25]$.

\section{Formulation of controlled release tablets}

Controlled release matrix tablets of fenoverine were prepared by using different concentrations of pullulan, HPMC K4M and HPMC K100M table 1. The entire excipients without talc were blended uniformly. After sufficient mixing of drug with other excipients, talc was added and further mixed for $5 \mathrm{~min}$. The prepared powder mass was compressed with $11 \mathrm{~mm}$ punch on multi tooling compression machine [Rimek II Karnavati Eng. Ltd. Ahmedabad] to give a tablet of $500 \mathrm{mg}$ weight.

Table 1: Formula for controlled release tablets

\begin{tabular}{|c|c|c|c|c|c|c|c|}
\hline Ingredients & F1 & F2 & F3 & F4 & F5 & F6 & F7 \\
\hline Fenoveine & 300 & 300 & 300 & 300 & 300 & 300 & 300 \\
\hline HPMC K4M & 120 & 150 & - & - & - & - & - \\
\hline HPMC K100M & - & - & 120 & 150 & - & - & - \\
\hline Pullulan & - & - & - & - & 120 & 150 & 180 \\
\hline Spray dried lactose & 60 & 30 & 60 & 30 & 60 & 30 & - \\
\hline Talc & 10 & 10 & 10 & 10 & 10 & 10 & 10 \\
\hline Magnesium stearate & 10 & 10 & 10 & 10 & 10 & 10 & 10 \\
\hline Total & 500 & 500 & 500 & 500 & 500 & 500 & 500 \\
\hline
\end{tabular}

Note: All quantities are given in $\mathrm{mg}$

\section{Evaluation of tablets}

\section{Hardness and thickness}

The hardness $\left[\mathrm{kg} / \mathrm{cm}^{2}\right]$ of the prepared formulations was determined by using a Monsanto hardness tester and thickness was measured by micrometre screw gauge $[\mathrm{mm}][\mathrm{n}=3]$ [22].

\section{Friability}

Friability of the prepared formulations was determined by using Roche friabilator [Campbell Electronics, Mumbai, India] [ $=20]$. The tablet samples corresponding to $6.5 \mathrm{~g}$ were weighed accurately, placed in the drum. Drum was rotated 100 times, and then tablets were removed. Any loose dust from the tablets was removed, and accurate weight was taken, and the $\%$ friability was calculated from the weight of tablets before and after test [22].

\section{Weight variation test}

The weight of the tablet is measured to ensure that a tablet contains the specific and accurate amount of drug and excipients. Twenty tablets were selected randomly and weighed. The average weight of the tablet was determined. Not more than the two of the individual weights deviate from the average weight by more than $5 \%$ and none deviates by more than $10 \%[\mathrm{n}=20]$ [22].

\section{Drug content uniformity}

Ten tablets were weighed and finely powdered, and powder equivalent to $300 \mathrm{mg}$ of drug was accurately weighed and dissolved in $0.1 \mathrm{~N} \mathrm{HCl}$ [pH 1.2 buffer]. The resulting solution was suitably diluted with $0.1 \mathrm{~N} \mathrm{HCl}[\mathrm{pH} 1.2$ buffer] and analyzed by Shimadzu UV spectrophotometer at $230 \mathrm{~nm}[13,22,31]$.

\section{In vitro drug release study}

The USP type II rotating paddle method was used to study the drug release from the controlled release tablet. The dissolution medium used was $900 \mathrm{ml} 0.1 \mathrm{~N} \mathrm{HCl}$ [buffer $\mathrm{pH} \mathrm{1.2].} \mathrm{The} \mathrm{release} \mathrm{study} \mathrm{was}$ performed at $37 \pm 0.5{ }^{\circ} \mathrm{C}$, with a rotation speed at $100 \mathrm{rpm}$. Sample volumes of $0.5 \mathrm{ml}$ were withdrawn at predetermined time intervals and filtered through $0.2 \mu \mathrm{m}$ Whatman filter paper and analyzed after appropriate dilution by Double beam UV spectrophotometer at 230 nm. Sink conditions were maintained throughout the study. The study was carried out in triplicate [13].

\section{Kinetics of in vitro drug release}

To study the release kinetics of in vitro drug release, data was treated with different kinetic equations such as Zero order (equation 1), First order (equation 2), Hixon-Crowel (equation 3), Higuchi (equation 4) and Korsmeyer-Peppas (equation 5).

\section{Zero order kinetics}

$$
\mathrm{W}=\mathrm{k}_{1} \mathrm{t}
$$

First order Kinetics

$$
\operatorname{In}[100-\mathrm{W}]=\operatorname{In} 100-\mathrm{kt}
$$

Hixon-Crowell's Cube-Root Equation [Erosion Model]

$$
\left[[10]^{\circ}-\mathrm{W}\right]^{1 / 3}=100^{1 / 3}-\mathrm{k}_{3} \mathrm{t}
$$

Higuchi's Square Root of Time Equation [Diffusion Model]

$$
\mathrm{W}=\mathrm{k}_{4} \mathrm{t} \mathrm{t} / 2 \cdots
$$

Korsmeyer peppers Equation [Diffusion/Relation Model]

$$
\mathrm{M}_{\mathrm{t}} / \mathrm{M}=\mathrm{k}_{5} \mathrm{t}^{\mathrm{n}}
$$

Where, $\mathrm{W}$ is $\%$ drug release at time $\mathrm{t}$ and $\mathrm{K}_{1}-\mathrm{K}_{4}$ are release rate constants, depending on the kinetic model used. $\mathrm{Mt} / \mathrm{M}$ is the fractional drug release into the dissolution medium and $\mathrm{K}_{5}$ is a constant incorporating the structural and geometric characteristics of the tablet. The term $\mathrm{n}$ is the diffusional constant that characterizes the drug release transport mechanism. When $n=0.5$, then the drug release mechanism is Fickian diffusion. If $\mathrm{n}<0.5$ the mechanism is quasi-Fickian diffusion, and $0.5<\mathrm{n}<1.0$, then it is non-Fickian or anomalous diffusion and when $\mathrm{n}=$ 1.0 mechanism is non Fickian case II diffusion or zero order release kinetics could be observed [23, 24].

\section{Stability studies}

Optimised formulation was sealed in aluminium packaging coated internally with polyethene, and kept instability chamber maintained at a temperature of $45^{\circ} \mathrm{C} \pm 2{ }^{\circ} \mathrm{C}$ and relative humidity $75 \% \pm 5 \%$ for $3 \mathrm{mo}$. Samples were withdrawn at 0, 30, 60 and 90 $\mathrm{d}$ and evaluated for the hardness, drug content and in vitro dissolution test [32]. 


\section{RESULTS AND DISCUSSION}

\section{FTIR study}

The IR spectrum of drug exhibited distinctive peaks at $1038.46[\mathrm{~cm}$ 1] due to C-N stretch [aliphatic amines] and peaks at $1234.24\left[\mathrm{~cm}^{-1}\right]$ due to $\mathrm{C}-\mathrm{N}$ stretch [aromatic amines]. The peaks at 1670.07 [cm-1] due to $\mathrm{C}=0$ stretching, peak at $2808.73\left[\mathrm{~cm}^{-1}\right]$ due to $\mathrm{C}-\mathrm{H}$ stretching, at $2964.65\left[\mathrm{~cm}^{-1}\right]$ due to $\mathrm{C}=\mathrm{C}-\mathrm{H}$ stretching and at $2931.26\left[\mathrm{~cm}^{-1}\right]$ due to $\mathrm{C}-\mathrm{C}-\mathrm{H}$ stretching fig. 1.

\section{DSC study}

The DSC thermogram of the drug depicted a peak at $141.29{ }^{\circ} \mathrm{C}$ corresponding to the melting transition temperature of fenoverine. This indicated that fenoverine drug was in pure state fig. 2.

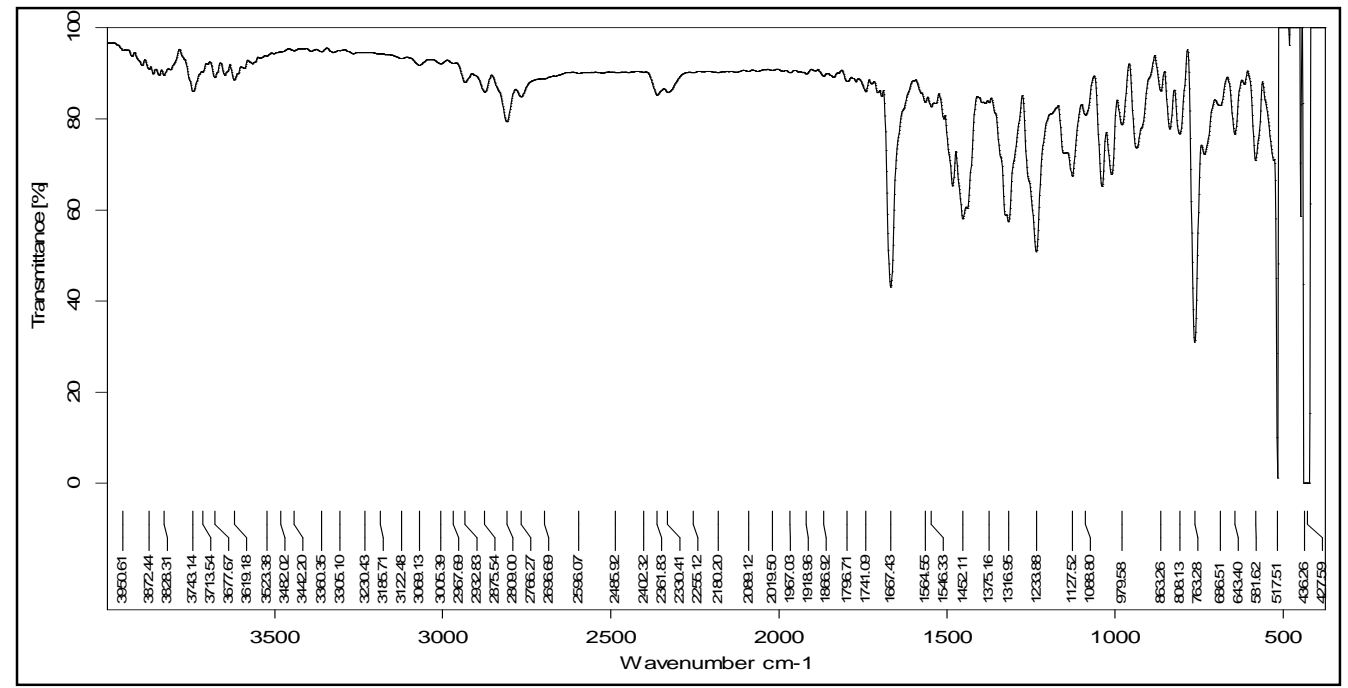

Fig. 1: FTIR spectrum of fenoverine Note-sample size $5 \mathrm{mg}$

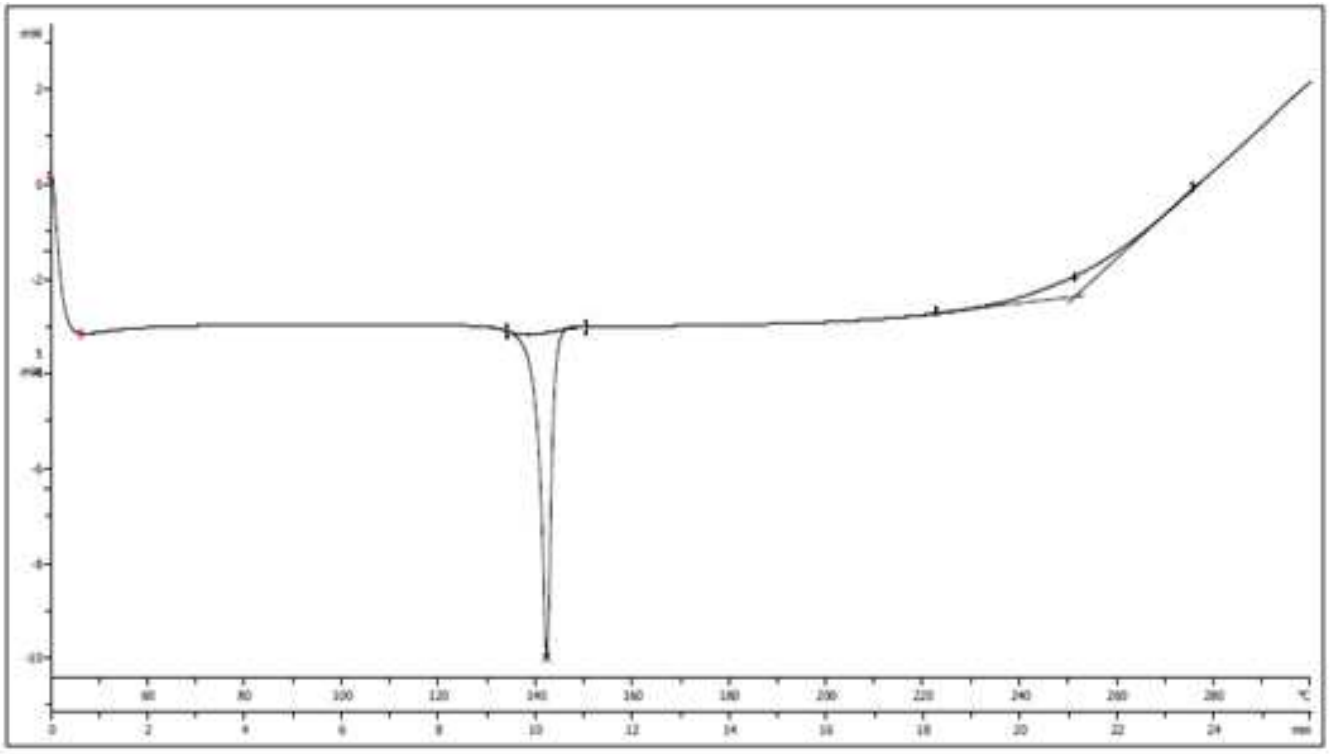

Fig. 2: DSC thermogram of fenoverine Note-Sample size $2 \mathrm{mg}$

\section{Drug-polymer compatibility study}

\section{FTIR study}

The IR spectra of pure drug and formulations were found similar with each other. The main absorption bands of the drug appeared in the formulation spectra shown in table 2, fig. 3, 4, 5. It was proved that the peaks found in pure drug and formulations are similar. Thus incorporation of drug in polymer did not change the position of its functional groups. This indicated that there was no difference between the internal structures and conformation of these samples at the molecular level. Hence FTIR study ruled out any possible interaction between drug and polymer.

\section{DSC study}

DSC thermogram of formulations containing pullulan, HPMC K4M and HPMC K100M fig. 6, 7, 8 showed a peak at $137.52{ }^{\circ} \mathrm{C}$, $141.14{ }^{\circ} \mathrm{C}$ and $140.76{ }^{\circ} \mathrm{C}$ respectively. There was no any significant shifting in the peaks of the drug, so it indicated that there was no any interaction between drug and formulation excipients in all thermogram. 
Table 2: FTIR spectra of fenoverine and formulations

\begin{tabular}{|c|c|c|c|c|c|c|}
\hline $\begin{array}{l}\text { S. } \\
\text { No. }\end{array}$ & $\begin{array}{l}\text { Standard wave } \\
\text { number fenoverine } \\
{\left[\mathrm{cm}^{-1}\right]}\end{array}$ & $\begin{array}{l}\text { Observed wave number } \\
\text { fenoverine }\left[\mathrm{cm}^{-1}\right]\end{array}$ & $\begin{array}{l}\text { Formulation } \\
\text { containing } \\
\text { pullulan } \\
{\left[\mathrm{cm}^{-1}\right]} \\
\end{array}$ & $\begin{array}{l}\text { Formulation } \\
\text { containing } \\
\text { HPMC K4M } \\
{\left[\mathrm{cm}^{-1}\right]}\end{array}$ & $\begin{array}{l}\text { Formulation } \\
\text { containing HPMC } \\
\text { K100M } \\
{\left[\mathrm{cm}^{-1}\right]}\end{array}$ & $\begin{array}{l}\text { Functional groups } \\
\text { associated }\end{array}$ \\
\hline 1 & 2810 & 2808.73 & 2807.20 & 2808.08 & 2810.96 & C-H Stretch \\
\hline 2 & 2973 & 2964.65 & 2968.26 & 2923.14 & 2967.26 & $\mathrm{C}=\mathrm{C}-\mathrm{H}$ Stretch \\
\hline 3 & 2930 & 2931.26 & 2920.84 & 2923.84 & 2927.31 & C-C-H Stretch \\
\hline 4 & 1672 & 1670.07 & 1668.06 & 1667.24 & 1668.50 & $-\mathrm{C}=0$ Stretch \\
\hline 5 & 1042 & 1038.46 & 1032.24 & 1035.72 & 1035.00 & $\begin{array}{l}\text { C-N Stretch } \\
\text { [Aliphatic amines] }\end{array}$ \\
\hline 6 & 1238 & 1234.24 & 1235.54 & 1234.08 & 1234.40 & $\begin{array}{l}\text { C-N Stretch } \\
\text { [Aromatic amines] }\end{array}$ \\
\hline
\end{tabular}

Note-cm-1-per centimeter, HPMC-hydroxy propyl methyl cellulose

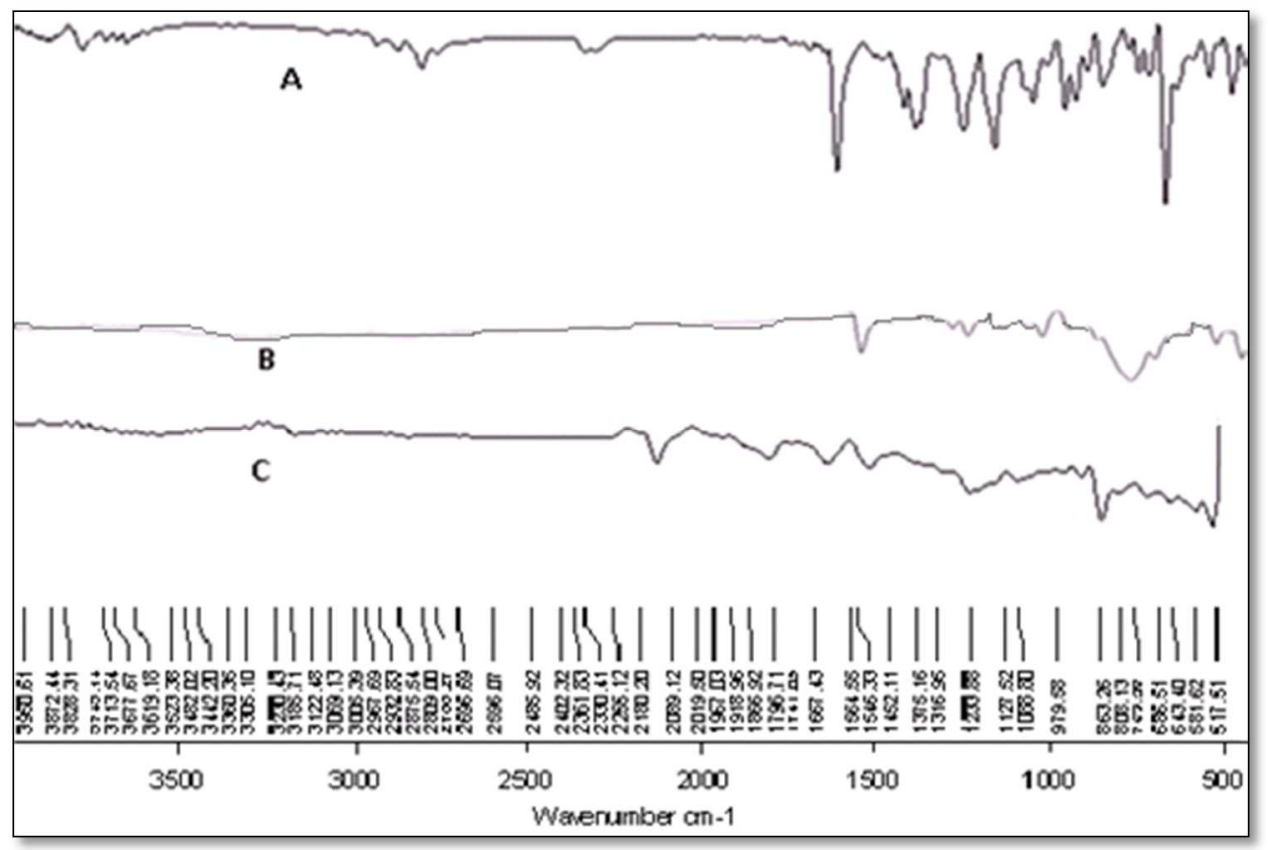

Fig. 3: FTIR spectra of A] Fenoverine B] Pullulan C] Formulation containing pullulan

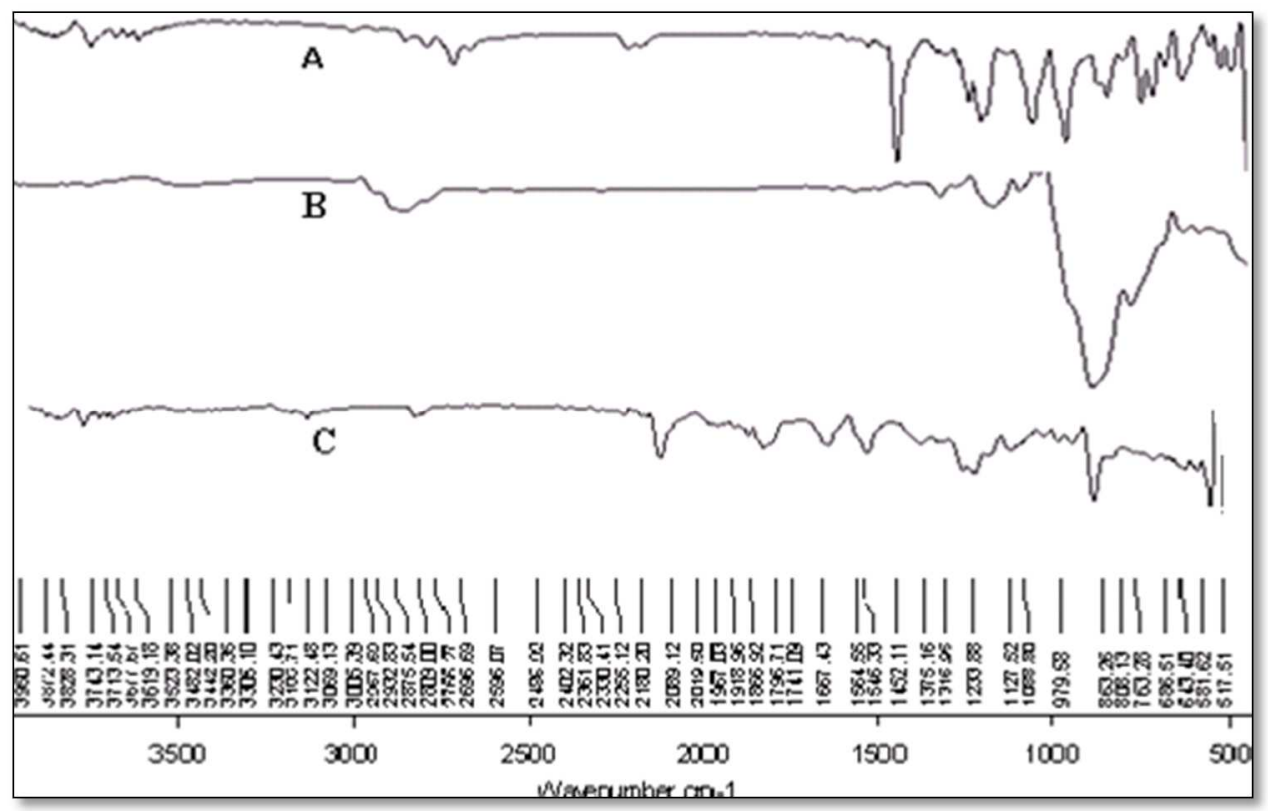

Fig. 4: FTIR spectra of A] Fenoverine B] HPMC K4M C] formulation containing HPMC K4M 


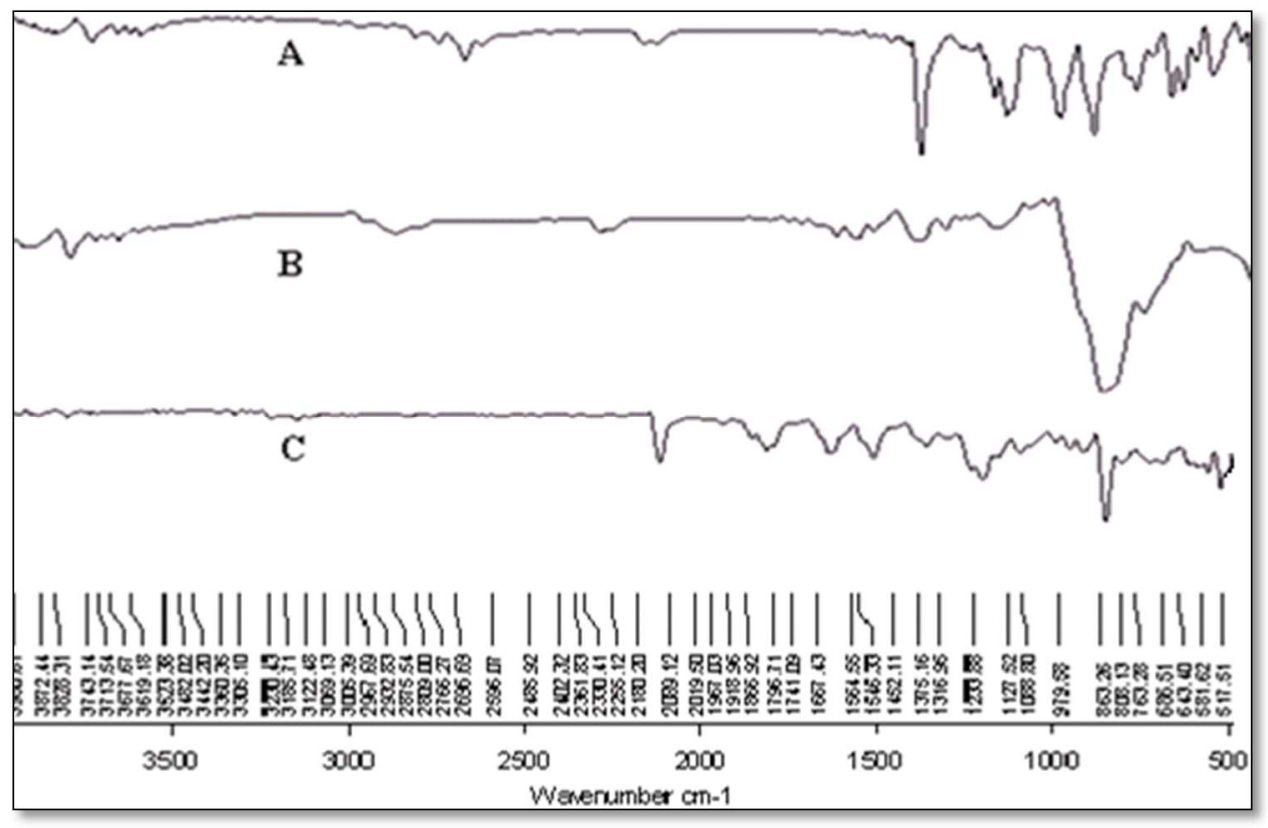

Fig. 5: FTIR spectra of A] Fenoverine B] HPMC K 100M C] formulation containing HPMC K100M

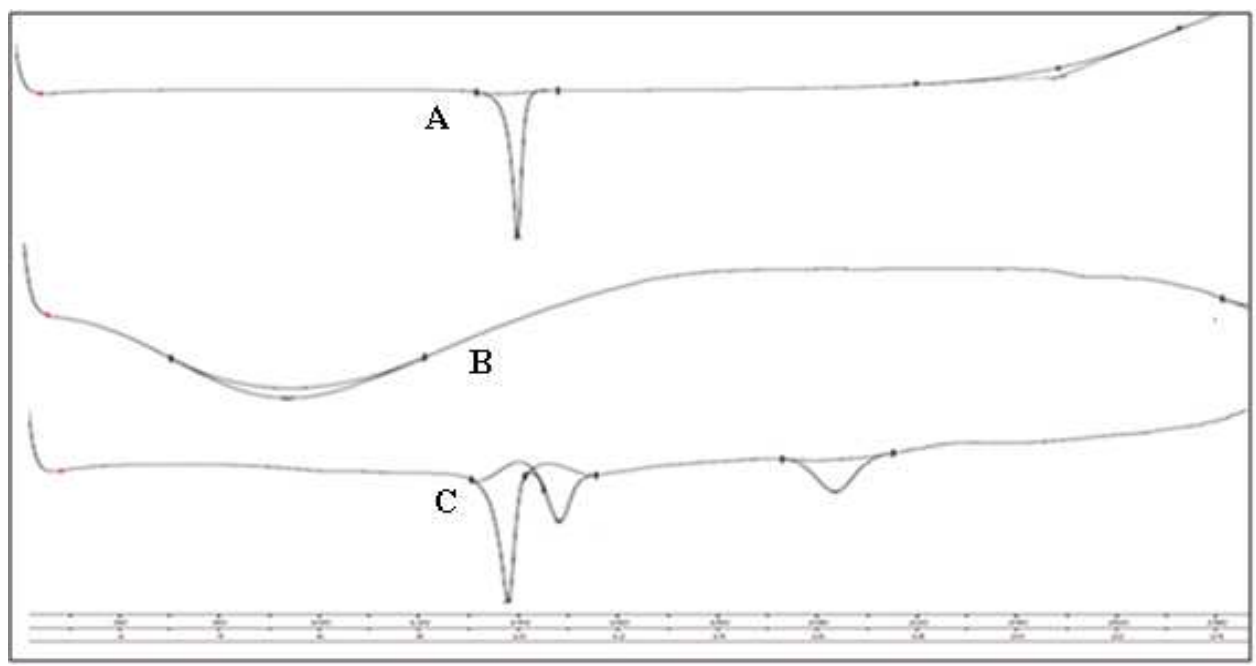

Fig. 6: DSC thermogram of A] Fenoverine B] Pullulan C] formulation containing pullulan

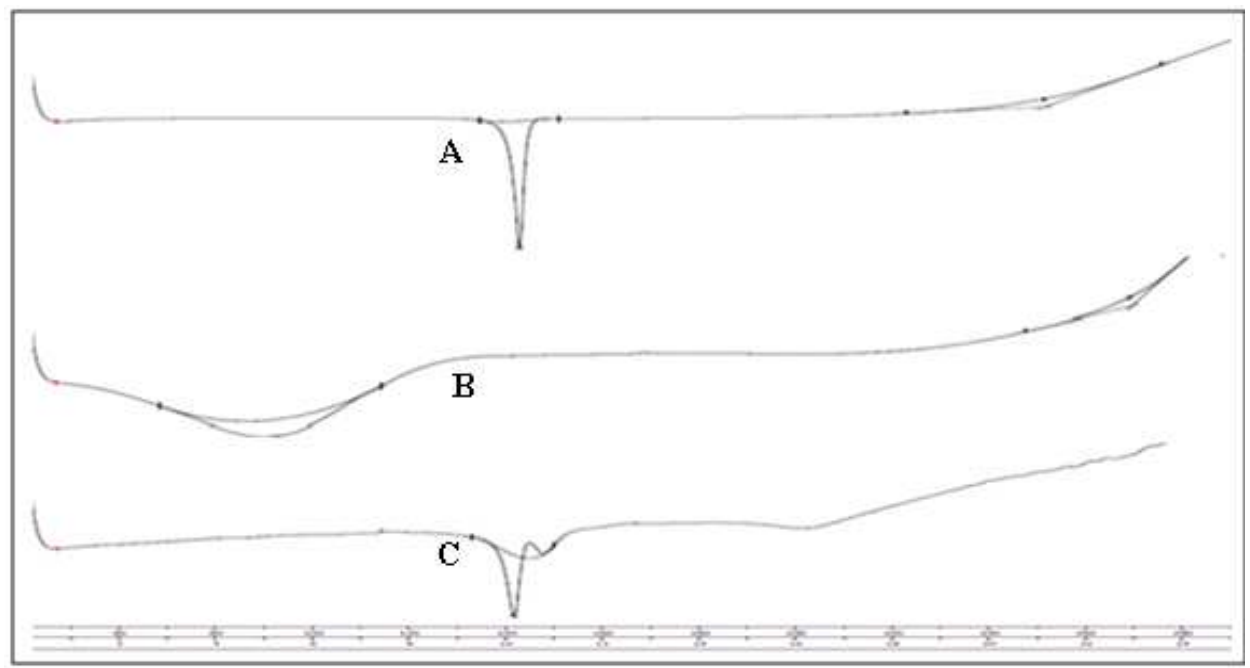

Fig. 7: DSC thermogram of A] Fenoverine B] HPMC K4M C] formulation containing HPMC K4M 


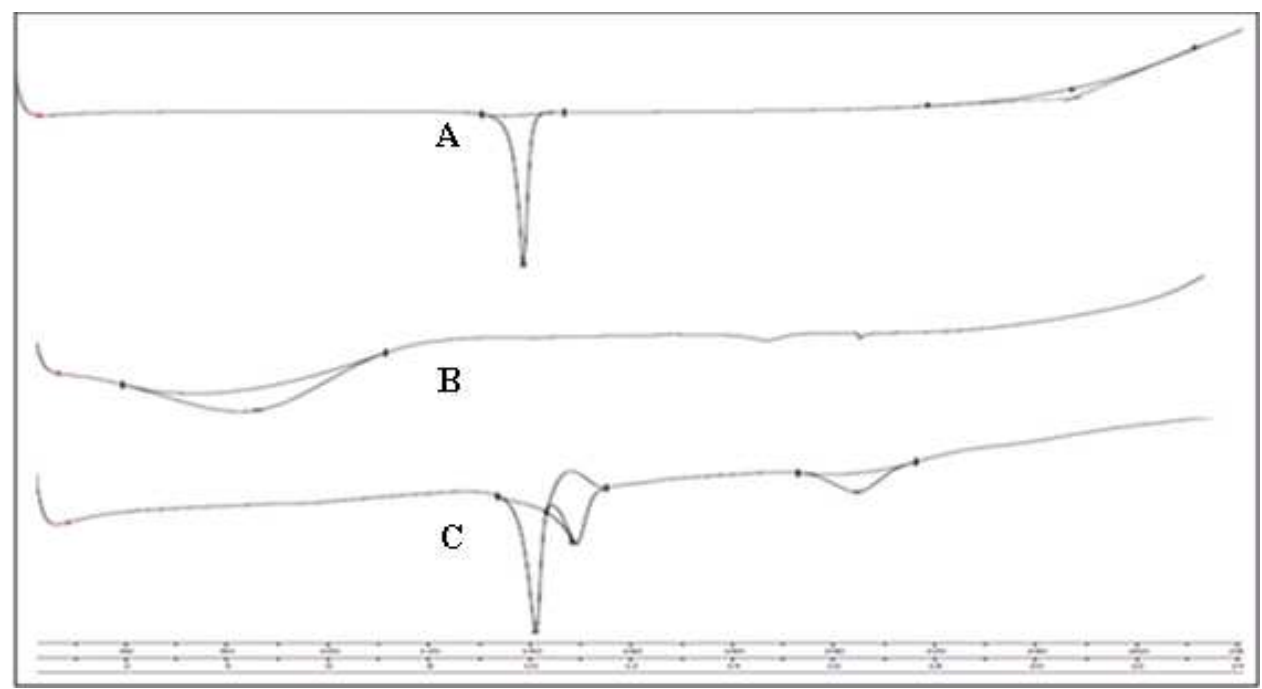

Fig. 8: DSC thermogram of A] Fenoverine B] HPMC K100M C] formulation containing HPMC K100M

\section{Evaluation of tablets}

\section{Hardness and thickness}

Hardness of tablets from all batches was found to be in the range of $4.5 \pm 0.003 \mathrm{~kg} / \mathrm{cm}^{2}$ to $4.9 \pm 0.006 \mathrm{~kg} / \mathrm{cm}^{2}$. All tablets were found hard enough so that they could easily withstand the handling and storage conditions without getting broken. Thickness of tablets ranged from $2.1447 \pm 0.02$ to $2.2866 \pm 0.13 \mathrm{~mm}$. This indicated [1] uniform die fill [2] uniform density [3] compression pressure applied was uniform and [4] drug particles have uniform size and shape.

\section{Friability}

All the tablets exhibited acceptable friability as none of the tested batches showed percentage friability that exceeded $1 \%$. As per IP, $\%$ friability below $1 \%$ is an indication of good mechanical resistance of the tablets. \% friability of all batches found in the range of $0.61 \%$ -
$0.78 \%$. Thus, it was proved that tablets could withstand the pressure, mechanical shocks during handling, transportation, storage and manufacturing processes.

\section{Weight variation test}

Weight variation test showed that all tablets were found within the range of $494.7 \mathrm{mg}-497.45 \mathrm{mg}$. None of the tablets deviated from the stated specification i.e. $\pm 5 \%$. It is in the limits specified by IP [22]. This indicated uniform flow property, die fill and compression pressure.

\section{Drug content}

Drug content of all the formulation batches was found to be between $95.7 \pm 0.002$ to $99.69 \pm 0.004$. Hence, it can be concluded that all the formulations are having accurate amount of drug distributed uniformly in powder mass and followed acceptable limits as per IP [22]. i.e. 85 to $115 \%$ of average content table 3 .

Table 3: Evaluation parameters of tablets

\begin{tabular}{lllll}
\hline Batches & Thickness $^{*}[\mathbf{m m}]$ & Hardness $^{*}\left[\mathbf{k g} / \mathbf{c m}^{2}\right]$ & Friability [\%] & Average Weight [mg] \\
\hline F1 & $2.227 \pm 0.09$ & $4.955 \pm 0.05$ & 0.65 & 496.63 \\
F2 & $2.227 \pm 0.07$ & $4.933 \pm 0.07$ & 0.75 & 497.45 \\
F3 & $2.278 \pm 0.11$ & $4.955 \pm 0.07$ & 0.78 & 497.26 \\
F4 & $2.257 \pm 0.14$ & $4.935 \pm 0.05$ & 0.65 & 495.76 \\
F5 & $2.286 \pm 0.13$ & $4.733 \pm 0.21$ & 0.68 & 494.7 \\
F6 & $2.198 \pm 0.04$ & $4.6 \pm 0.17$ & 0.66 & 496.32 \\
F7 & $2.147 \pm 0.02$ & $4.622 \pm 0.21$ & 0.61 & 495.99 \\
\hline
\end{tabular}

$*$ mean \pm SD $[\mathrm{n}=3]$

\section{In-vitro release study}

The results of in-vitro dissolution study given in table 4 and in fig. 9, it was observed that an increase in polymer concentration from 24 to $30 \%$ (F1-F2 and F3-F4) and from 24 to $36 \%$ (F5 to F7) there is a decrease in release rate. The drug release from formulations containing HPMC K100M (F3-F4) was found to be less as compared to other formulations. This might be due to slow hydration of matrix and its property to form a thick gel layer, which retards the drug release from the tablet. Whereas formulations containing pullulan [F5-F7] gave higher drug release as compared to other formulations, which may be due to quick hydration and erosion of polymer matrix. As compared pullulan, HPMC polymers are less hydrophilic and require more time to get hydrated. In addition to the concentration of polymer matrix, the type and viscosity of polymer also influence on drug release.

In-vitro dissolution study data shows cumulative drug release was in the order like $\mathrm{F} 5>\mathrm{F} 1>\mathrm{F} 6>\mathrm{F} 2>\mathrm{F} 7>\mathrm{F} 3>\mathrm{F} 4$. This might be due to the nature, viscosity and concentration of the various polymers used. Pullulan has powerful retardant property resulting in a matrix formation which is required for sustained release formulations. The data also indicated that because of quick hydration and erosion of pullulan polymer there was more drug release in $2 \mathrm{~h}, 4 \mathrm{~h}, 6 \mathrm{~h}$ etc. as compared to HPMC polymers. Formulation F5 was considered as optimized formulation as it showed highest cumulative \% drug release i.e. $96.82 \pm 0.75 \%$ at the end of $12 \mathrm{~h}$.

The tablets with pullulan polymer showed comparative dissolution profile with tablets with HPMC polymers and showed drug release rate retarding properties.

\section{Kinetics of in vitro drug release}

The in vitro release data obtained were fitted into various kinetic models Optimized batch F5 showed case II transport mechanism $[\mathrm{n}>1]$ i.e. drug transport mechanism associated with stresses and 
state transition in hydrophilic glassy polymers which swell in water or biological fluids, also includes polymer disentanglement and erosion and followed zero order release pattern showed in table 5 . So, predominant drug release mechanism is controlled release.

Table 4: In vitro dissolution study

\begin{tabular}{|c|c|c|c|c|c|c|c|}
\hline \multirow{2}{*}{$\begin{array}{l}\text { Time } \\
{[\mathrm{H}]}\end{array}$} & \multicolumn{7}{|l|}{ \% CDR* } \\
\hline & F1 & F2 & F3 & F4 & F5 & F6 & F7 \\
\hline 0 & 0 & 0 & 0 & 0 & 0 & 0 & 0 \\
\hline 1 & $1.89 \pm 0.14$ & $6.45 \pm 0.13$ & $5.73 \pm 0.7$ & $3.07 \pm 0.48$ & $12.89 \pm 0.73$ & $8.54 \pm 0.55$ & $11.92 \pm 0.72$ \\
\hline 2 & $7.29 \pm 0.46$ & $10.14 \pm 0.42$ & $12.26 \pm 0.25$ & $11.64 \pm 0.91$ & $19.74 \pm 0.64$ & $13.21 \pm 0.3$ & $14.88 \pm 1.25$ \\
\hline 3 & $11.03 \pm 0.12$ & $13.19 \pm 0.39$ & $15.89 \pm 0.38$ & $11.84 \pm 0.62$ & $25.68 \pm 1.22$ & $17.38 \pm 0.66$ & $18.72 \pm 0.53$ \\
\hline 4 & $13.73 \pm 0.59$ & $16.33 \pm 0.64$ & $20.61 \pm 0.58$ & $16.42 \pm 0.91$ & $33.07 \pm 0.6$ & $19.89 \pm 0.74$ & $21.63 \pm 0.92$ \\
\hline 5 & $17.67 \pm 0.4$ & $18.39 \pm 0.42$ & $23.96 \pm 0.49$ & $20.56 \pm 1.22$ & $43.71 \pm 0.17$ & $24.76 \pm 0.56$ & $25.5 \pm 0.27$ \\
\hline 6 & $21 \pm 0.19$ & $22.77 \pm 0.48$ & $31.44 \pm 0.33$ & $30.75 \pm 0.74$ & $54.04 \pm 0.5$ & $29.21 \pm 1.13$ & $39.16 \pm 0.23$ \\
\hline 7 & $31.49 \pm 0.32$ & $40.34 \pm 0.6$ & $40.06 \pm 0.18$ & $43.78 \pm 0.65$ & $62.21 \pm 0.76$ & $36.06 \pm 1.11$ & $43.58 \pm 0.52$ \\
\hline 8 & $49.13 \pm 0.26$ & $54.38 \pm 0.59$ & $52.82 \pm 1.06$ & $53.5 \pm 0.55$ & $69.42 \pm 0.41$ & $48.41 \pm 0.38$ & $49.94 \pm 0.98$ \\
\hline 9 & $53.89 \pm 0.21$ & $67.59 \pm 0.31$ & $60.38 \pm 0.3$ & $60.99 \pm 0.78$ & $77.05 \pm 0.64$ & $56.74 \pm 0.9$ & $62.19 \pm 0.69$ \\
\hline 10 & $61.52 \pm 0.23$ & $72.62 \pm 0.47$ & $67.51 \pm 0.48$ & $67.47 \pm 0.98$ & $83.09 \pm 0.16$ & $66.48 \pm 0.79$ & $66.51 \pm 1.18$ \\
\hline 11 & $67.32 \pm 0.23$ & $75.5 \pm 0.51$ & $73.44 \pm 1.47$ & $71.95 \pm 1.12$ & $88.27 \pm 0.57$ & $74.18 \pm 1.04$ & $79.68 \pm 0.14$ \\
\hline 12 & $88.62 \pm 0.16$ & $85.34 \pm 0.92$ & $80.12 \pm 0.8$ & $78.12 \pm 0.99$ & $96.82 \pm 0.75$ & $85.96 \pm 0.69$ & $83.77 \pm 0.42$ \\
\hline
\end{tabular}

* mean \pm SD $[\mathrm{n}=3]$

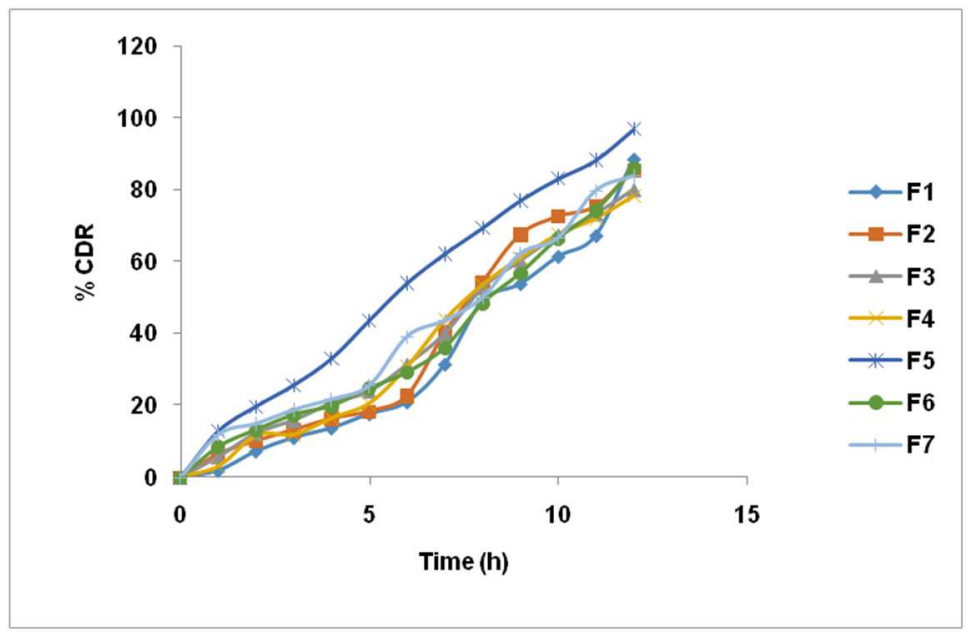

Fig. 9: In vitro drug release profile of formulations F1 to F7 Note-error bars omitted

Table 5: Study of various kinetic models

\begin{tabular}{|c|c|c|c|c|c|c|c|}
\hline \multirow[t]{2}{*}{ Batch } & \multirow{2}{*}{$\begin{array}{l}\text { Zero order } \\
\mathbf{r}^{2}\end{array}$} & \multirow{2}{*}{$\begin{array}{l}\text { First order } \\
\mathbf{r}^{2}\end{array}$} & \multirow{2}{*}{$\begin{array}{l}\text { Higuchi } \\
\mathbf{r}^{2}\end{array}$} & \multirow{2}{*}{$\begin{array}{l}\text { Hixson-Crowell } \\
\mathbf{r}^{2}\end{array}$} & \multicolumn{2}{|c|}{ Korsemeyer-peppas } & \multirow[t]{2}{*}{ Best fit model } \\
\hline & & & & & $\mathbf{r}^{2}$ & $\mathbf{n}$ & \\
\hline F1 & 0.946 & 0.696 & 0.869 & 0.939 & 0.973 & 1.889 & K-peppas \\
\hline $\mathrm{F} 2$ & 0.942 & 0.957 & 0.872 & 0.968 & 0.985 & 1.700 & K-peppas \\
\hline F3 & 0.983 & 0.902 & 0.933 & 0.969 & 0.992 & 1.636 & K-peppas \\
\hline $\mathrm{F} 4$ & 0.973 & 0.782 & 0.928 & 0.928 & 0.928 & 1.736 & K-peppas \\
\hline F5 & 0.994 & 0.920 & 0.976 & 0.960 & 0.983 & 1.594 & Zero order \\
\hline F6 & 0.958 & 0.979 & 0.882 & 0.994 & 0.983 & 1.606 & H. Crowell \\
\hline F7 & 0.955 & 0.982 & 0.880 & 0.992 & 0.979 & 1.601 & H. Crowell \\
\hline
\end{tabular}

\section{Stability studies}

Short-term stability studies of the optimised formulation indicated that there were no significant changes in hardness, drug content and in vitro dissolution studies at the end of three months period table 6,7 , and fig. $10, P<0.05$. Similarity factor $f 2$ of dissolution profiles of optimized formulation F5 before and after stability study was found to be 89 , which indicated similar dissolution profiles before and after stability study.

Table 6: Stability study data of formulation F5

\begin{tabular}{llll}
\hline Parameters & 0 Mo & 1 Mo & 2 Mo \\
\hline Hardness $^{*}\left[\mathrm{~kg} / \mathrm{cm}^{2}\right]$ & $4.7 \pm 0.2$ & $4.7 \pm 0.2$ & $4.6 \pm 0.1$ \\
Drug content* $[\%]$ & $99.69 \pm 0.004$ & $99.57 \pm 0.01$ & $98.59 \pm 0.09$ \\
\hline
\end{tabular}

*mean \pm SD $[\mathrm{n}=3]$ 
Table 7: In vitro dissolution study of formulation F5 before and after stability

\begin{tabular}{|c|c|c|c|c|}
\hline \multirow{2}{*}{$\begin{array}{l}\text { Time } \\
{[\mathrm{H}]}\end{array}$} & \multicolumn{4}{|c|}{ Cumulative $\%$ drug release at } \\
\hline & O Mo & $1 \mathrm{Mo}$ & 2 Mo & 3Month \\
\hline 0 & 0 & 0 & 0 & 0 \\
\hline 1 & $12.89 \pm 0.73$ & $12.80 \pm 0.01$ & $12.44 \pm 0.31$ & $12.10 \pm 0.11$ \\
\hline 2 & $19.74 \pm 0.64$ & $19.55 \pm 0.5$ & $19.41 \pm 0.26$ & $18.45 \pm 0.01$ \\
\hline 3 & $25.68 \pm 1.22$ & $25.39 \pm 0.37$ & $25.23 \pm 0.01$ & $24.50 \pm 0.33$ \\
\hline 4 & $33.07 \pm 0.6$ & $33.00 \pm 0.53$ & $32.84 \pm 0.13$ & $32.06 \pm 0.05$ \\
\hline 5 & $43.71 \pm 0.17$ & $43.56 \pm 0.45$ & $43.25 \pm 0.17$ & $42.30 \pm 26$ \\
\hline 6 & $54.04 \pm 0.5$ & $54.11 \pm 0.09$ & $53.98 \pm 0.01$ & $53.16 \pm 0.01$ \\
\hline 7 & $62.21 \pm 0.76$ & $62.1 \pm 0.11$ & $61.94 \pm 0.06$ & $61.06 \pm 0.07$ \\
\hline 8 & $69.42 \pm 0.41$ & $69.09 \pm 0.12$ & $68.79 \pm 0.27$ & $68.20 \pm 0.13$ \\
\hline 9 & $77.05 \pm 0.64$ & $76.86 \pm 0.15$ & $76.35 \pm 0.13$ & $75.24 \pm 0.07$ \\
\hline 10 & $83.09 \pm 0.16$ & $83.09 \pm 0.01$ & $82.97 \pm 0.01$ & $81.17 \pm 0.05$ \\
\hline 11 & $88.27 \pm 0.57$ & $88.11 \pm 0.01$ & $87.77 \pm 0.27$ & $86.13 \pm 0.01$ \\
\hline 12 & $96.82 \pm 0.75$ & $96.42 \pm 0.20$ & $95.30 \pm 0.12$ & $94.63 \pm 0.26$ \\
\hline
\end{tabular}

$*$ mean \pm SD $[\mathrm{n}=3]$

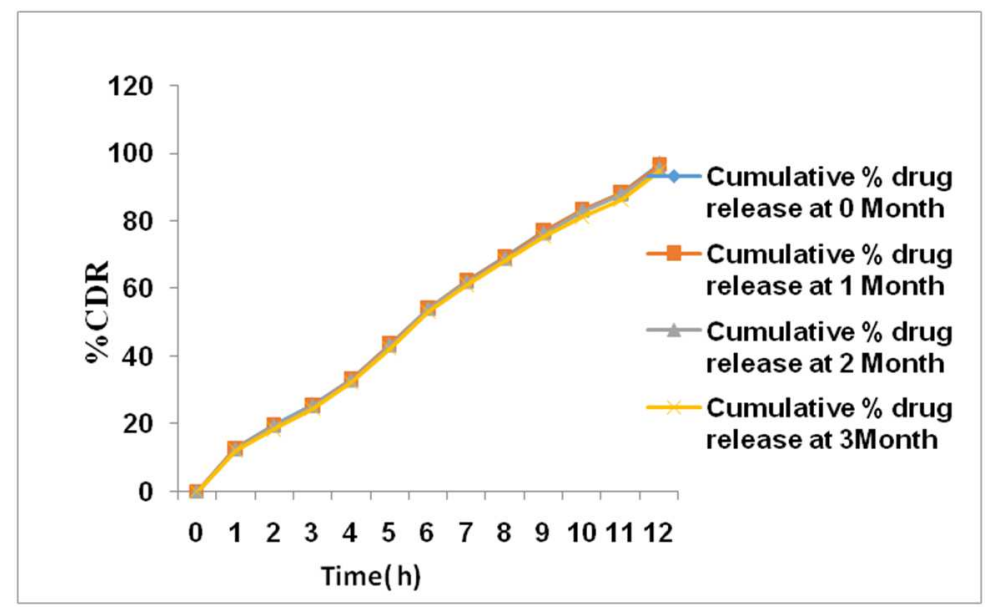

Fig. 10: Dissolution profile of formulation F5 before and after stability study Note-error bars omitted

\section{CONCLUSION}

Fenoverine controlled release matrix tablets were prepared by using different concentrations of pullulan, HPMC K4M and HPMC K100M by direct compression method and evaluated. FTIR and DSC studies indicated that there were no drug-excipients interactions. In vitro drug release study showed that, as the amount of polymer increases, the drug release decreases. Optimized batch F5 showed case II transport mechanism and followed zero order release kinetics. Short-term stability studies of the optimized formulation indicated that there was no significant change observed in hardness, drug content and in vitro dissolution studies. Similarity factor $f 2$ was found to be 89 , which indicated similar dissolution profiles before and after stability study. Pullulan a novel natural polymer showed drug release controlling characteristics. Hence it can be concluded that pullulan can be used as a polymer for retarding the release of drug from matrix formulations.

\section{ACKNOWLEDGEMENT}

The authors are thankful to the Euro Drug Laboratories; Hyderabad, Andhra Pradesh, India and Satara College of Pharmacy, Satara, [MS] India for providing necessary facilities to carry out this work.

\section{CONFLICTS OF INTERESTS}

Declare none

\section{REFERENCES}

1. Joshi K, Dhole S, Doltode A. Formulation and in vitro evaluation of sustained release matrix tablet of dicyclomine hydrochloride by using hydrophilic polymers. Int J Pharm Sci Res 2014;5:1331-8.
2. Ashok Kumar P, Damodar Kumar S. Design and evaluation of controlled release matrix tablets of acyclovir. DPL 2013;5:347-53.

3. Asija R, Modi J, Kumawat R, Asija S, Goyal M. Formulation and evaluation of diclofenac sodium sustained release tablets using melt granulation technique. Int J Pediatr 2012;3:216-20.

4. Chien YW. Novel drug delivery systems. 2nd Ed. New York: Marcel Dekker Inc; 1992. p. 139-60.

5. Tapaswi RD, Varma P. Matrix tablets: an approach towards oral extended release drug delivery. Int J Pharma Res Rev 2013;2:12-24.

6. Moses P, Subramanian L, Palanichamy S, Jeganath S, Thanga Thirupathi A. Formulation and evaluation of ciprofloxacin controlled release matrix tablets. DPL 2010;2:237-43.

7. Ramana G, Reddy KD, Sravanthi O. Design and evaluation of natural gum based oral controlled release matrix tablets of ambroxol hydrochloride. DPL 2012;4:1105-14.

8. Nokhodchi A, Shaista R, Patel P, Asare-Addo K. The role of oral controlled release matrix tablets in drug delivery systems. Bioimpacts 2012;2:175-87.

9. Chatap VK, Maurya AR, Prashant K, Deshmukh, Zawar LR. Formulation and evaluation of nisoldipine sublingual tablets using pullulan and chitosan for rapid oromucosal absorption. APP 2013;1:18-25.

10. Maurya AR, Chatap VK, Deshmukh PK, Mullurwar VK, Bari Sanjay B. Pullulan as a novel solubilizer for solubility enhancement of nisoldipine. NSIJPS 2012;1:374-85.

11. Maryadele J, Neil O, Smith A, Patricia E. The Merck index: an encyclopedia of chemicals, drugs, and biological, Merck and Co. Inc.; 2001. p. 705. 
12. Sweetman SC, Martindale: The complete drug reference. $35^{\text {th }}$ ed. Vol. I. PhP Pharmaceutical Press; 2007. p. 2091.

13. USP, Fenoverine Monograph, USP Medicines Compendium $<12>$, Drug Product Performance; 2014.

14. Yamsani MR, Bandari S, Eaga CM, Thadishetty A. Formulation and evaluation of multiple tablets of as a gastro retentive floating drug delivery system for fenoverine. Acta Pharm 2010:60:89-97.

15. Sudke SG, Sakarkar DM. Application of hot-melt coating for sustained release pellets of fenoverine. DPL 2013;4:153-9.

16. Sudke SG, Madhusudan RY, Sakarkar DM. Formulation and release behaviour of sustain release fenoverine HPMC matrix tablets. Int J Univers Pharm Bio Sci 2013;2:491-500.

17. Gubbi S, Jarag R. Atorvastatin calcium liquisolid compacts. Afr J Plant Sci 2010;5:50-60.

18. Gowree Manogar P, Vedha Hari BN, Ramya Devi D. Emerging liquisolid compact technology for solubility enhancement of BCS class-II drug. J Pet Sci Res 2011;3:1604-11.

19. Beckett AH, Stenlake JB. Practical pharmaceutical chemistry. $4^{\text {th }}$ ed. Part-II, CBS publishers and distributors pvt ltd IR; 2007. p. 379-407.

20. Pavia, Lampman, Kriz, Vyvyan, Spectroscopy. India ed. Cengaze learning, IR; 2007. p. 26-92.

21. Nokhodchi A, Amire O, Jelvehgari M. Physico-mechanical and dissolution behaviors of ibuprofen crystals crystallized in the presence of various additives. DARU 2010;18:74-83.

22. Indian Pharmacopoeia 2010. p. 218-20.

23. Anuj Patnaik N, Nagarjuna T, Thulasiramaraju TV. Sustained release drug delivery system: a modern formulation approach. Int J Res Pharm Nano Sci 2013;2:586-601.

24. Brahmankar DM, Jaiswal SB. $2^{\text {nd }}$ ed. Biopharmaceutics and pharmacokinetics: a treatise, Vallabh Prakashan; 2009. p. 431-3.
25. Dhurke R, Diddi S, Shareef S. Development of colon-specific multi-particulate drug delivery system of fenoverine. Int J Pharm Pharm Sci 2014;6:227-31.

26. Kulkarni AS, Deokule HA, Mane MS, Ghadge DM. Exploration of different polymers for use in the formulation of oral fast dissolving strips. J Curr Pharma Res 2010;2:33-5.

27. Rupavath M, Ramkrisha K. Formulation and evaluation of floating matrix tablets of stavudine using pullulan gum. Int J Chem Pharm Sci 2012;3:80-3.

28. The opinion of the scientific panel on food additives, flavorings, processing aids and materials in contact with food on a request from commission related to Pullulan PI-20 for use as food additive. EFSA J 2004;85:1-32.

29. Amin A, Mishra R. Formulation and characterization of rapidly dissolving films of cetrizine hydrochloride using pullulan as a film forming agent. Indian J Pharm Educ Res 2011;45:71-7.

30. Aulton ME. Aulton's Pharmaceutics, The design and manufacture of medicines. $3^{\text {rd }}$ ed. Philadelphia, USA, Churchill Livingstone Elsevier; 2008. p. 99-102.

31. Deodhar P, Nareshkumar K, Ganesh G, Mukkanti K, Chandra Sekhara. UV-Spectrophotometric and extractive colorimetric methods for determination of fenoverine from bulk drug and its pharmaceutical formulation. J Pharm Res 2012;5:3406-9.

32. Stability studies in an overview of ICH guidelines for drug products. Natalie Mc Clure, Matrix Pharmaceutical Inc.; 1997. Available from: http://www.mcclurenet.com. [Last accessed on 20 Oct 2017]

\section{How to cite this article}

- $\quad$ Ajit Kulkarni, Trushali Mandhare, Nagesh Aloorkar. Application of novel natural polymer for controlling the release of fenoverine from controlled release matrix tablets. Int J Appl Pharm 2017;9(2):1-9. 